\title{
Local livelihoods and global process: complex causalities in Hong Kong's Sai Kung Peninsula
}

\begin{abstract}
This paper looks at the changes that occurred in the rural area of the Sai Kung Peninsula in Hong Kong's New Territories from the 16th century, and uses it as a case-study to show the complex range of forces that can act on a locale. Throughout its history, land use and economic activities on the Sai Kung Peninsula have been driven to a great extent by non-local factors, including distant warfare leading to mass immigration and political decisions leading to mass emigration. However, once Hong Kong became an important outpost of Britain's colonial empire it became integrated into a global trade network and thus became sensitive to economic and technological changes taking place thousands of miles away. In the 20th century, the Sai Kung Peninsula developed in response to Hong Kong's growth as an international trade hub, finding its agricultural output overwhelmed by cheap foreign products, and its industry challenged by foreign technological advances.
\end{abstract}

Keywords

Rural livelihoods - Political economy - Colonisation - Decolonisation • Hong Kong

(C) University of Warsaw - Faculty of Geography and Regional Studies
Claudio O. Delang

Hong Kong Baptist University

Kowloon Tong, Hong Kong

e-mail: cdelang@hkbu.edu.hk

Received: 21 January 2018

Accepted: 1 March 2018

\section{Introduction}

It is inevitable that locales experience considerable changes over time, driven by factors such as technological developments, economic growth, and environmental changes. However, rarely are major long-term changes more evident than in areas which experience the impacts of colonisation and decolonisation. These locales are not only subject to gradual changes in environmental and socio-economic conditions, but also feel the compounding effects of the major socio-political shocks that come from drastic changes in political authority within a short period of time, as well as the effects of the laws and regulations that come from these authorities.

In addition to the particular laws and regulations that influence life in colonial and post-colonial locales, land use, livelihood, and economic changes are also driven by complex networks of interacting factors originating at both local and global levels, as well as, critically, those structural elements within the networks that connect these two levels (Lambin et al. 2001). Due to the integration of colonies within the global economic networks of the individual imperial powers, colonised regions have often provided historical prototypes for the interaction of local and global forces. In the post-colonial world, distinct imperial networks have been replaced by a less fractured and more holistic globalisation, leading to an intensification of some of the trends seen in the colonial period. The increasingly frictionless nature of global flows of goods, capital and information suggests that we should treat all areas of the world as inextricably bound into a single complex system that can only be understood by bringing the 'distant' and the 'local' together, rather than separating them out.

This article examines the nature of the relationship between local and distant drivers of change through the study of the history of the Sai Kung peninsula in Hong Kong's 'New Territories' and, in particular, developments in the village of Sheung Yiu over the last five centuries. Sheung Yiu, and the Sai Kung peninsula more generally, provide a valuable microcosm for understanding the complexities of the interacting forces that drive land use change and serve in this article as a case-study that throws light on the relationship between the local and the global.

The New Territories form the rural 'hinterland' of Hong Kong, having been added to the British colony in 1898 on the basis of a 99-year lease. The acquisition of the New Territories was intended to improve the defensibility of Hong Kong island and the Kowloon peninsula granted to the British in the wake of the First and Second Anglo-Chinese Wars, respectively. As is the case with the rest of Hong Kong, the New Territories have experienced considerable changes during the period discussed in this paper, transitioning from Chinese rule to British and back to Chinese in the course of a century.

A critical change stemming from its position as a major eastern outpost of the Empire is that over the last 150 years Hong Kong has become a key location for global trade, first within the Empire and its successor the Commonwealth, and then operating under a unique set of laws as a part of China. As such, a variety of both distant and local forces and trends have exerted a powerful influence on local economic opportunities. By studying the Sai Kung Peninsula we can see just how complex is the network of factors influencing livelihood changes and how inadequate are both simplistic generalised models and narrow, geographically bounded analyses of developments in one small area. 
Information for this paper comes from published sources as well as semi-structured interviews of former inhabitants of the Sai Kung Peninsula. Four different periods have been identified from a political perspective and the paper has been organised chronologically to make the transformations easier to follow.

\section{From the $16^{\text {th }}$ Century to the $18^{\text {th }}$ Century}

From the mid-Tang dynasty to the early Ming dynasty (1368$1644)$, the area of what is now Hong Kong was a part of China's Dongguan County. However, as Hong Kong was far away from the administrative centre of the county and had a rough coastline, the inhabitants suffered from regular pirate incursions and were not in a position to benefit much from the protection of the county government. In response to this difficulty, the Ming government created Xin'an County (新安縣) in 1573, under the control of Guangzhou prefecture (Faure 1986, p. 14), to rule Hong Kong and the surrounding area.

In 1644, the Ming Dynasty fell to the Manchu, who were to rule China under the Qing Dynasty for the next two and a half centuries (AD 1644-1911). However, in the early years of Qing rule there was still significant resistance from the former Ming Dynasty in southern China. These resistant powers were eventually defeated by the Qing armies in the following decade and the army of 'loyalist pirate-warrior' Zheng Chengong (鄭成功) left the mainland in the hands of its new overlords and retreated to Taiwan. Zheng Chengong developed the island into a base for anti-Qing sympathizers who wanted to restore the Ming Dynasty to power. Some coastal residents of mainland China who objected to Manchu rule over the Chinese remained sympathetic to the Ming cause and continued to provide food, support, and financial assistance to Zheng.

As a consequence, the Qing government enacted a policy of 'Coastal Evacuation' in 1661 (the eighteenth year of the Shunzhi Emperor), leading to a 'massive depopulation of southern China' (Sinclair et al. 2007, p. 17). The government 'order[ed] the inhabitants of the Fujian and Guangdong coasts to move inland 30 to $50 \mathrm{Ii}^{1}$ (Cheng 2003, p. 8) and 'guard posts were set up within the New Territories, manned by the military' (Faure 1986, p. 15) with the aim of breaking down the support of the coastal population for Zheng Chengong and his forces. According to Cheng (2003, p. 8), the evacuated areas were garrisoned by the army and Sai Kung was included amongst them, leading to great suffering for the villagers who were forbidden to fish in their traditional waters, had their houses burned down, and were forced to abandon their lands. Nevertheless, from the perspective of the Qing government, the evacuation was largely ineffective, so, in 1664 (the third year of the Kangxi Emperor), they acted to push the displaced population a further $30 \mathrm{li}(19.34 \mathrm{~km})$ inland to reinforce the strategy of separating the Ming loyalists on Taiwan from their supporters. Over $80 \%$ of Xin'an County was inside the affected area during the second phase of the evacuation. Local villagers were unable to maintain their livelihoods under such conditions and there were, inevitably, huge losses of both life and property.

In the following years, the Qing government managed to constrain and then push back their opponents, eventually defeating them and taking over the governance of Taiwan in 1683. This progress led to a gradual relief of the implementation of the coastal evacuation between 1669 and 1683. Unfortunately, very few original residents survived to return to Sai Kung and the New Territories, while 'many Hakka from outside came and settled in the area' (Cheng 2003, p. 8). The new inhabitants, 'from the northern and eastern Guangdong, Fujian, and Jiangxi Provinces'

'The ' $l$ ' (里) is a Chinese unit used to measure distance. Over time, the value changed: one $l i$ had a value of 644.65 metres in the Qing Dynasty and since 1984 it is standardised as 500 metres. The Coastal Evacuation since the mid-16th century coastal residents inland for $19.34 \mathrm{~km}$ to $32.23 \mathrm{~km}$, according to the value of a $l i$ in the Qing Dynasty.

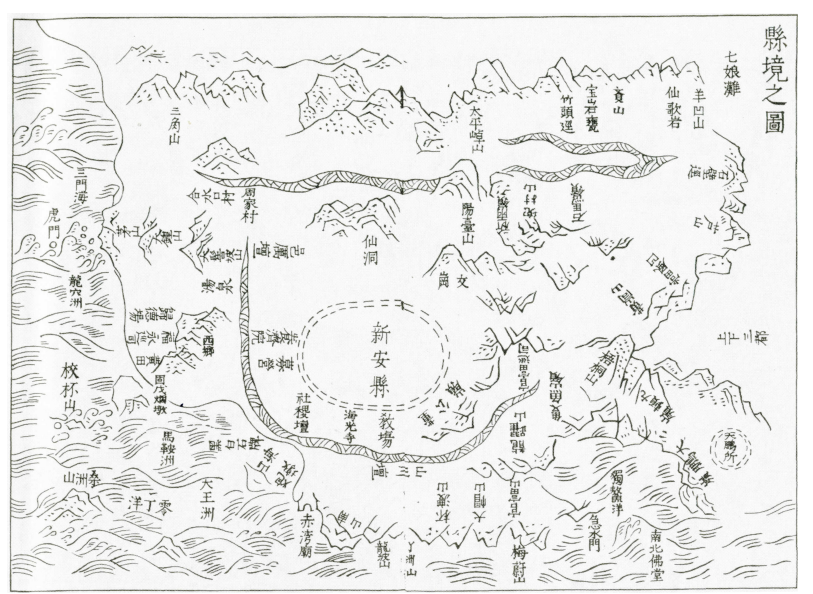

Figure 1. The 1688 published by the Xin'an County government Source: Liu (1999 p. 5)

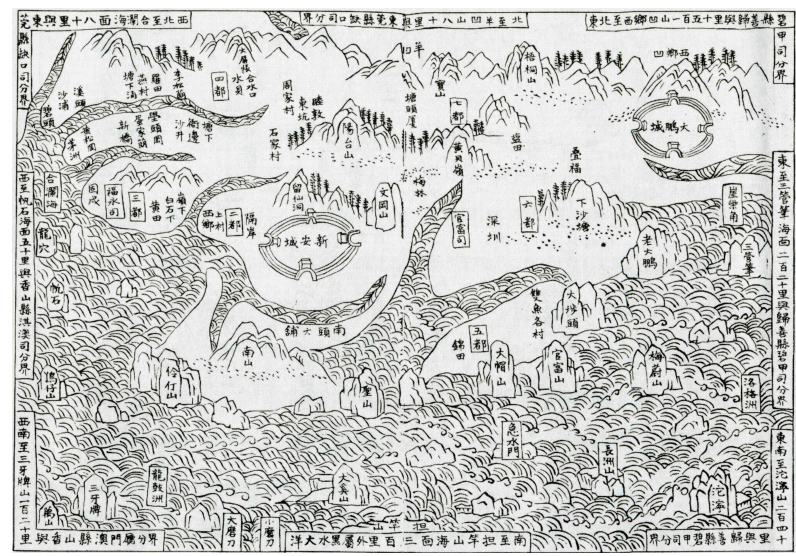

Figure 2. The 1819 gazetteer published by the Xin'an County government

Source: Liu (1999 p. 6)

(Rao 1998, p. 13), were for the most part farmers and fishermen. The farmers established their villages in the valley and on some limited areas of coastal flatland on the Sai Kung Peninsula, while the fishermen predominantly stayed on the islands or the coastal bays (Figure 1).

Between the late $17^{\text {th }}$ and the late $18^{\text {th }}$ centuries, many Hakka people migrated from northern Guangdong Province to Hong Kong, later moving on to the Sai Kung Peninsula where they built their villages, which even today form the majority of settlements on the peninsula (Ma et al. 2003). In the 1819 gazetteer (Figures 2, 3), 854 villages were listed within the county as a whole, of which 13 were located in Sai Kung and owned by Puntis and Hakkas. Very little information about the individual villages is available (Faure 1986, p. 15), but archaeological discoveries allow us to see that the Hakka people 'engage[d] in agricultural cultivation in the valley and the coastal area' and the 'early settlers primarily made their living by farming or fishing, while a few engaged in manufacturing sugar or salt' (AMO 2005, p. 24).

Despite the limitations of the historical records for the early history of Sai Kung, we can already see that patterns and distribution of land use were determined by a combination of local and distant factors. Conflict in the north of China initially drove migration south and this force interacted with local geography 


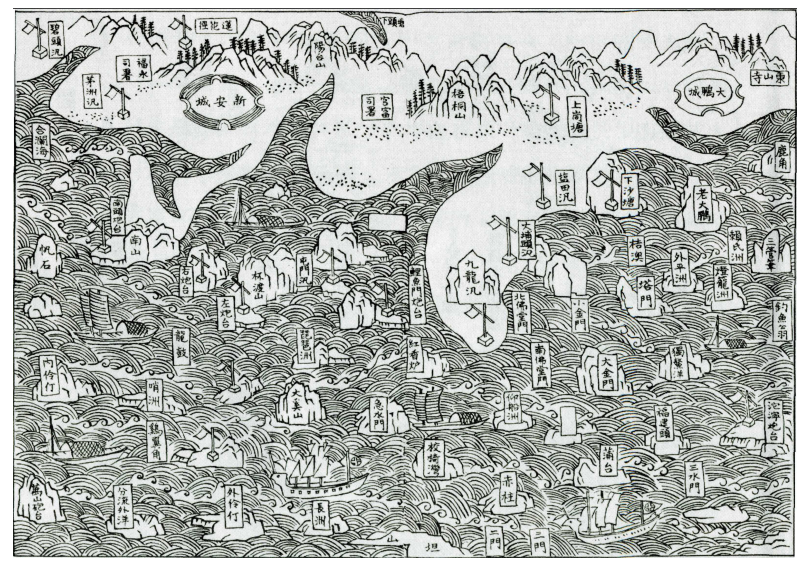

Figure 3. The 1819 naval gazetteer published by the Xin'an County government

Source: Liu (1999 p. 6)

and socio-economic considerations to determine the location of new settlements and, consequently, the types of economic activities the new arrivals were able to engage in. A second period of conflict, this time between the Manchu and the remnants of the Ming regime, led to the almost complete forced depopulation of the area, and then its gradual repopulation, as tensions eased. This repopulation saw the ethnic balance tip decisively in favour of the Hakka peoples, a movement that was solidified by further phases of immigration in the late $17^{\text {th }}$ and the late $18^{\text {th }}$ centuries. It is difficult to specify the exact motivations of each wave of immigrants but the conditions in the distant areas from which they moved must certainly have been a significant push factor that acted in combination with the pull of Sai Kung.

\section{The $19^{\text {th }}$ Century}

In the late $18^{\text {th }}$ century, Europeans began travelling to China to trade but their activities were restricted to Guangzhou (Canton) through an import-export monopoly body called 'Cohong' (公行). The increasing contacts between the Chinese and the Europeans (especially the British) led to conflicts due to different interests and cultural values, eventually resulting in the First Anglo-Chinese War between 1839 and 1842. In 1842, China was defeated and the Treaty of Nanjing officially ceded Hong Kong Island to the British. In 1860 a further Chinese defeat in the Second AngloChinese War saw the British obtain the Kowloon Peninsula under the terms of the First Convention of Peking. Sai Kung remained under the rule of China's Xin'an County at this time.

After the failure of the First Sino-Japanese War in 1894, the Qing government was faced with further aggressive attempts to secure concessions by a number of other European countries, including France, Germany, and Russia. As a result, the British forced the Qing government to lease them the New Territories, with the purpose of improving the defensibility of Hong Kong. ${ }^{2}$ In June 1898, China and Britain signed an agreement 'To Extend the Boundary of Hong Kong' (Cheng 2003, p. 10), which defined the boundary of the New Territories and permitted British control over the territory for 99 years, from July $1^{\text {st }} 1898$ until June $30^{\text {th }}$ 1997. Sai Kung, which was still underdeveloped at that time, now came under the control of the British. According to Lockhart

${ }^{2}$ According to Sinclair, et al. (2007, p. 12), the leasing of the New Territories was 'principally needed to protect Hong Kong's vital harbour' and 'provide[d] much needed space to expand the city and ... help[ed] in defending the island and shipping'; meanwhile, the colonial government also aimed at 'eradicating pirates holed up on surrounding islands who ceaselessly harassed shipping'.
$(1898)^{3}$, most of the villages on the Sai Kung Peninsula contained fewer than 100 people, with only 13 settlements having a larger population.

\section{Changes from 1899 to 1941}

The second phase of economic development on the Sai Kung Peninsula occurred during the late $19^{\text {th }}$ century, during which time the people living along the coast became significantly richer due to the increasing importance of the fishing industry. The development of Hong Kong as a centre for Britain's eastern trade created increasing demands for locally produced goods to sustain the growth in population. With the persistently growing demand for fish of both the fresh and salted kinds, as well as for fuel and construction materials, the Sai Kung Peninsula flourished. Along the coast of the peninsula, villagers produced construction materials for a living, making, for example, lime and bricks for house-building in both the town and the rural villages.

Prior to the census conducted by the Hong Kong government in 1911, there had not been 'an even remotely reliable population report' (Faure 1986, p. 15) since the 1819 gazetteer. In 1911, the population in Sai Kung was 9,243 , or $13.4 \%$ of the population of the whole New Territories. Among these 9,243 people, $60 \%$ spoke the Hakka dialect, nearly $25 \%$ were Cantonese, and the remaining were Hoklo ${ }^{4}$ and Tanka, 'a kind of sea-gipsy' (Hong Kong Government 1913, p. 44).

\section{Economic Activities and the Development of Hong Kong}

With the colonisation of Hong Kong and its development as a port from the mid-19 $9^{\text {th }}$ century, as well as the British expansion into the New Territories in the late $19^{\text {th }}$ century, the economic horizons of the residents of the New Territories broadened considerably. Although sources are scarce and not very reliable, the population of Hong Kong is estimated to have increased tenfold in the first quarter century of British rule to 87,000 (Schenk 2008). By the time of the 1911 census that number had climbed to some 450,000 , including those living in the New Territories, and then grew further to 840,000 by 1931 . Economic opportunities came from the demand for 'various rural products' (Faure 1986, p. 19) in Hong Kong and Kowloon, so the 'poorer coastal villages' benefited 'more immediately than the inland communities' (Faure 1986, p. 19). In the markets of Hong Kong and Kowloon, the demand for food, fuels and building materials was extremely high and the villagers of the New Territories were able to adapt by supplying these needs.

In the case of foodstuffs, people living in the city relied on the provision of fresh fish and pork from the New Territories, so the Hoklo and Tanka, or 'boat population' 'benefited directly from this trade' (Faure 1986, p. 19). Most of the fishing activities in Sai Kung were carried out by large junks (Hong Kong Government 1913, p. 53) which would spend up to ten days at a time at sea, travelling 'to a distance of 100 miles or more from land' (Hong Kong Government 1913 , p. 53). Fish supplies included both fresh and salted fish, so fishermen brought large amount of salt for the preservation of their catch. Fish were dried 'on board or on shore and sold to the shops in the nearest port' (Hong Kong Government 1913, p. 53), such as that on High Island (Leung Shuen Wan), with the port acting like an agency for the big salt fish firms. Activities in the fishery sector flourished between October and May each year but the remaining months were dangerous, as 'winds were unreliable'

\footnotetext{
3Sir James Haldane Stewart Lockhart, KCMG (1858-1937) was a British colonial official in Hong Kong and China for more than 40 years. In mid-summer of 1898, he spent 12 days in the New Territories to study village conditions as well as people's livelihood 'from small hamlets' to 'the sizeable market towns' (Sinclair 2007, p. 14), and wrote the Report on the New Territories 1899-1912.

${ }^{4}$ Hoklo is the name of an ethnic group which is now distributed mainly in Taiwan, Fujian
} and other parts of Southern China, as well as scattered areas of Southeast Asia. 
(Hong Kong Government 1913, p. 53) and typhoons plagued the sea during the summer. In addition to their trade in fish, the people of Sai Kung also benefited from the commercialisation of 'pigraising', and some shops even made 'loans to villagers on the security of pigs that were to be raised' (Faure 1986, p. 19).

As far as fuel was concerned, whether people lived in the city or in rural areas they all depended on firewood and the New Territories became the dominant supplier for the growing urban population. According to Sir J.H. Stewart Lockhart, nearly all the small villages were 'surrounded by groves of trees' (Hong Kong Government 1913, p. 44). Taking advantage of the forested hillsides of the Sai Kung Peninsula, many women from the rural villages gathered and sold firewood. According to Ma et al. (2003), these women had to bring the firewood out to the town in the early morning at around 2 to $3 \mathrm{am}$ and then returned to the village some twelve hours later. Those who lived in the northern part of the peninsula would go to Sai Kung Town or Tai Po Town for trade while villagers from the southern part would travel to Sai Kung Town and Kowloon City. Firewood was often sold in Kowloon City and the vendors would buy rice or other food items for their return.

Taking the Wong family in Sheung Yiu village as an example, there is a large piece of woodland located at the backyard of the Wong's house. The primary reason for the planting of woodland is due to fengshui, the traditional Chinse principle of harmonisation with the environment surrounding a village. However, the fengshui also provided a valuable fuel supply for the private use of villagers and an additional motivation for planting was the production and sale of firewood for economic gain.

In terms of building materials, lime-making and, later, brickmaking were the crucial village industries at Pak Tam Chung. Lime was widely used not only as a building material but also for making fertilizer, pesticide, sugar, the hulls of boats, paper, dyes, and many other products (Rao 2001). The Pak Tam Chung area can be regarded as an industrial area at that time, since villages could collect coral from the nearby Port Shelter to make lime (Faure 1986). Villagers in Sheung Yiu not only owned lime kilns (Figure 4) but also operated a brick kiln on the opposite shore.

The economic activities of fishermen were naturally concentrated in the coastal area or the bays along the Sai Kung Peninsula, as these areas provided fishermen with shelter from the wind, allowing them to repair and dry nets and maintain their tools. In the 1930s to 1940s, there were at least 30 boats anchoring at High Island (Ma et al. 2003) and a number of shops provided the fishermen with the necessary items, such as firewood, hay and food. These shops also provided facilities for fishermen to repair and maintain their nets.

\section{Villages in the Pak Tam Chung Area}

According to Faure (1986), in 1911 there were six villages in Pak Tam Chung with fewer than 405 inhabitants: Wong Yi Chau (黃宜洲), Pak Tam (北潭), Sheung Yiu (上窑), Tsak Yu Wu (鯽 魚湖), Wong Keng Tei (黃慶地) and Tsam Chuk Wan (斬竹灣) (Hayes 1995, p. 21). The six villages were all inhabited by Hakka people, with the exception of two hamlets in Pak Tam. There were four hamlets located around Sheung Yiu village, namely Pak Tam Chung hamlet (北潭涌村), Tai Wong hamlet (大黃村), Sheung Yiu hamlet (上窑村), and Hei Tsz Wan hamlet (起子灣村) Intensive agricultural activities were carried out in these villages. At the same time, as mentioned above, the Pak Tam Chung area was also something of an industrial zone, with the villagers there benefiting from 'being able to obtain coral from Port Shelter that was used to make lime' (Faure 1986, p. 90) while villagers in Sheung Yiu operated a brick kiln, called "Opposite Kiln", on the opposite shore.

Sheung Yiu hamlet (Figures 5, 6) was founded by Wong FatSing and members of the Wong clan, Hakkas who had moved

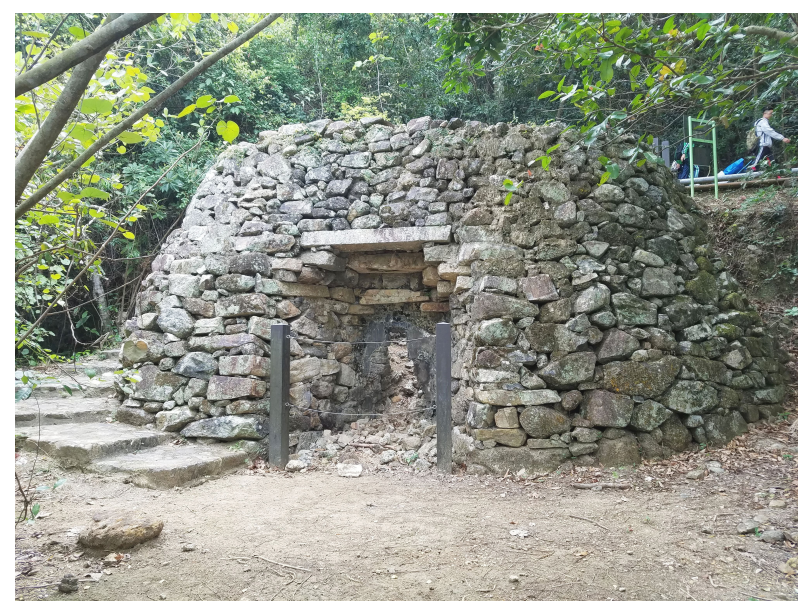

Figure 4. Lime kiln operated by the Wongs' of Sheung Yiu village photo: C. Delang

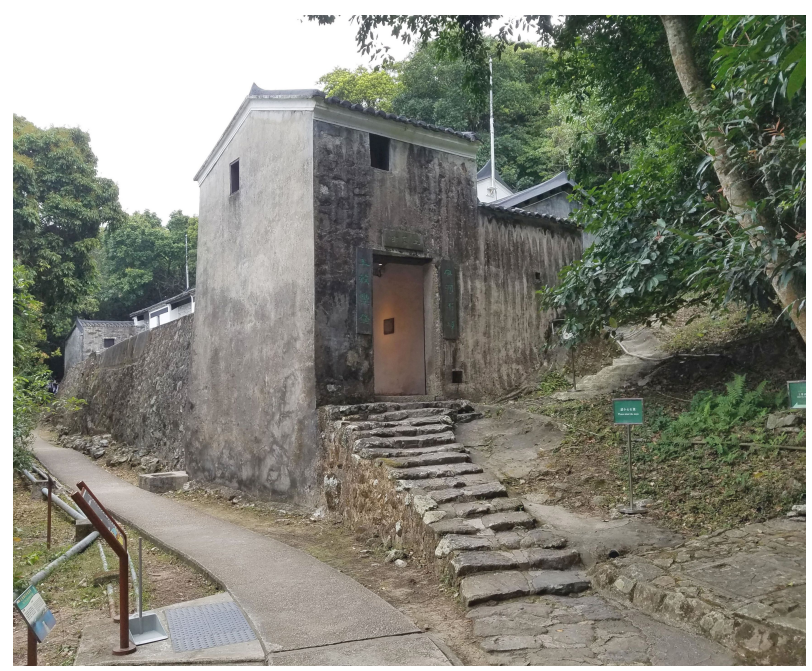

Figure 5. Sheung Yiu hamlet photo: C. Delang

to Sai Kung from their ancestral home in Baoan County in Guangdong Province in the late 19th century. Settling near Pak Tam Chung, they set up a small shop to try and make a living providing local villagers, passers-by and travelling tradesmen with a place where they could find refreshment and rest. This small initial complex formed the nucleus around which the village would grow, expanding to take advantage of the existing opportunities.

The dominant economic activities in Sheung Yiu Village were fishing, farming and the manufacturing of lime, bricks and tiles for use in building and farming. Rich in coral (skeletons) and shells, the Sai Kung seashore in the vicinity of Sheung Yiu Village provided abundant raw materials for manufacturing lime, which the Wong family exploited, building a lime $\mathrm{kiln}^{5}$ on the side of the footpath as well as a brick kiln in Wong Keng Tei. The confluence of salt and fresh water at the mouth of the Lung Hang River helped the fast growth of the coral, and villagers were able to collect coral and shells by means of long bamboo rakes (Sinclair et al. 2007). As the Wong family started involving itself in other profitable activities, the village grew to house other family

${ }^{5}$ The lime kiln was built of stream-rounded stones outside, and coarse bricks inside, similar to other lime kilns found elsewhere of Hong Kong (Stokes 2004). 
members and their businesses. Many of the inhabitants of nearby hamlets, some of whom had come to Saikung from the same mainland village, worked in the Wong family's kilns.

This was a prosperous time for the Wong family. After collecting the coral and shellfish, villagers put them in the lime kiln for burning for 'seven days and then cooling for 10 days' and 'the reduced coral was sold as construction materials or fertilizer' (Sinclair et al. 2007, p. 36). In addition, they 'made mortar and fertilizer as well as lime bricks and tiles' (Sinclair et al. 2007, p. 34). Since road transport was hindered by the physical constraints of an underdeveloped road system, villagers in Sheung Yiu Village relied on water transport. All products were transported on boats and villagers 'would load lime bricks and kindling and sail from' the river 'to places like Chai Wan and sell them' (Sinclair et al. 2007, p. 34).

As a self-contained community, the food supply of the fellow villages relied on three sources: a) farming in order to obtain products from the rice paddy fields; b) fishing to acquire fish and other seafood from the Pak Tam Chung channel, a wetland estuary with high biodiversity; and c) planting and harvesting of fruits such as litchi (lychee) and longan around the village, including in the fengshui grove. Life in the village existed at a subsistence level; villagers would buy whatever they could not produce with the proceeds from selling lime, wood, and possibly a rice surplus, when they needed something produced outside their community (Sinclair et al. 2007).

The main reasons for the Wong family's development of the lime-making industry in this area were economic and were driven by complex local and distant factors. First, the area was rich in coral and seashells, which enabled a constant supply of raw materials for lime manufacturing. Secondly, the pier next to the village provided easy access to water-borne transportation. ${ }^{6}$ In addition, the plantation of fengshui woodland provided a steady supply of wood and timber. This was an essential element in lime manufacturing, as the industry demanded a large quantity of fuel to sustain itself. While these local features provided the villagers with valuable resources to exploit, the viability of exploiting them was driven by the economic development of Hong Kong as a whole and thus depended not just on the regional urban centre but also on the robustness of the global trade flows that passed through Hong Kong.

Politically, the Wong family were unable to build up their industrial operations in the northern New Territories any further, because 1) they were latecomers in comparison to the Five Clans in the northern New Territories who had arrived during the Ming and Sung Dynasties; 2) lands in the northern New Territories, such as Yuen Long and San Tin were owned by the Five Clans, awards presented by the Emperor; and 3) the Wongs were only merchants with a low social status, in contrast to the people of the Five Clans, who traditionally formed part of the scholarly/ bureaucratic class. $^{7}$

\section{The Japanese Occupation: 1942-45}

The Japanese 'full scale invasion' of China started on July $7^{\text {th }}, 1937$. Its successes in China encouraged Japan to start the Pacific campaign in 1941 with its attack on Pearl Harbour. Japan carried the war to Hong Kong on December $8^{\text {th }}$, 1941. After 18 days of fighting, the British Governor, Sir Mark Aitchison Young, surrendered on Christmas Day. Hong Kong remained under the harsh occupation of the Imperial Japanese forces for three years and eight months, from December 25 $5^{\text {th }}, 1941$ to August $15^{\text {th }}, 1945$.

\footnotetext{
${ }^{6}$ From Stokes (2004, p. 197), it is believed that the concrete pier which still exists today was the 'original family pier for junks and sampans' (a kind of small boat in traditional Chinese society)

${ }^{7}$ The social status among traditional Chinese is: Scholars > Peasants > Craftsmen > Merchants
}

Life was hard during the occupation and lives in Sai Kung were even harder than most, since the peninsula was the stronghold of the Hong Kong Independent Battalion of the Dong Jiang column (東江縱隊港九獨立大隊), a Chinese anti-Japanese fighting body. At that time, large groups of men from the Hakka villages in Sai Kung put their farming activities aside and joined the group to fight against the Japanese. The guerrilla force was divided into two columns. The land column was stationed in the villages of Cheung Sheung, Ko Tong and Chek Keng, with the commissariat quartered in villages in Pak Tam Chung. The water column controlled the eastern seaboard of the Sai Kung Peninsula and used the Tin Hau Temple in Leung Shuen Wan Village on High Island as their base. Food supply during the occupation was insufficient, so the anti-Japanese fighting body secretly employed villagers to carry the much-needed rice supply, sent from mainland China, from the pier in To Kwa Peng (a bay at the northern coast of Sai Kung Peninsula) to the commissariat base in Pak Tam Chung.

The income of the column largely depended on tax stations operated both on land and on sea, and the provision of convoy services to the boats. Different products would have different tax rates levied against them. For instance, goods were taxed at a rate between $5 \%$ and $10 \%$, while fishery products were taxed at a lower rate, of between $3 \%$ and $5 \%$ (Ma et al. 2003). Villages in Ko Tong, along Kwun Mun Channel and on High Island served as tax stations during this period. In addition to these stations, the column also controlled some small-shop businesses and the fisheries wholesale market, using these as cover for their activities against the Japanese army.

Life in the villages was hard during this period. In addition to the Japanese army pressuring the villagers for intelligence about the guerrillas and for workers to construct roads and military facilities, bandits also robbed the villages of food and money. In the first year of the occupation, both the Japanese military and bandits commandeered grain and livestock from the villages. In Tai Long Village, 'bandits came [to the village] every several days' (Centre for East Asian Studies 1980, p. 34) and villagers sometimes had to resort to feeding themselves with leaves and laver (Ma et al. 2003). Bandits were seen throughout the peninsula, in both wealthy and poor villages (Centre for East Asian Studies 1980, p. 34). Later, the Japanese authorities imposed food rationing ${ }^{8}$ but these measures were inadequate and villagers relied on tapioca, seaweeds, roots, leaves, and even bark to feed themselves (Centre for East Asian Studies 1980; Ma et al. 2003). As a result, many people starved.

Fishermen were in a better position, as they were less susceptible to raiding. Many were able to continue their lives as before, fishing and salting their catch for sale in Shau Kei Wan. While there were bandits in the vicinity of some fishing villages, they do not seem to have taken advantage of the villagers. For example, according to villagers from Pak Lap Village, Pak A Village and Tung A Village, there were bandits on High Island at that time but they left the villagers undisturbed (Centre for East Asian Studies 1980).

\section{The Post-War Period: 1950-1968}

At the end of the war, Hong Kong was returned to British control but the new peace was now threatened by civil war in China between the Nationalists and Communists (1946-1949). Fear of the communists combined with social unrest to send large numbers of refugees fleeing to Hong Kong during this time. Hong Kong's population quickly rose from its nadir of 600,000 at the end of the war, passing through its pre-war peak of 1,800,000 in 1947 and reaching an estimated $2,500,000$ by 1956 . The first

${ }^{8}$ Food subject to rationing included rice, oil, flour, salt and sugar; each person could buy 6.4 taels $(0.24 \mathrm{~kg})$ of rice per day. 
official post-war census in 1961 put the population at 3,129,648 and five years later a second census counted $3,716,400$. The extremely high rate of growth put enormous pressures on the Hong Kong government in terms of feeding and housing newcomers and these pressures heavily influenced, in turn, the activities of villagers in the New Territories.

Despite the increasing need for products such as construction materials and food traditionally produced in places like Sai Kung, there was no economic boom to match that of the pre-war years. On the contrary, rice farming declined considerably throughout the 1950s, 60s and 70s in most of the New Territories (Hayes 1995), with many young villagers moving out of the rural areas. While Hong Kong grew, the proportion of locally grown food declined sharply. Indeed, rice production declined so precipitously that by the 1980s Hong Kong produced very little, relying almost entirely on foreign imports, a situation that continues today. Already in the 1960 s the colony relied on imports for $60 \%$ of its vegetables but this figure rose to $70 \%$ in the 1970 s and then to $80 \%$ in the 80 s and 90 s. Similar falls can also be seen in livestock consumption. Increasingly efficient trade corridors meant that local producers were increasingly unable to compete effectively.

The lack of modern transport infrastructure was a further factor affecting the viability of agricultural production in Sai Kung. There was no road development in the peninsula until 1959 so villagers were forced to either carry their goods along footpaths or, more commonly, rely on water transport. The major food products of Sai Kung - taro, ginger, sweet potatoes and beans - were all bulky, exacerbating the problem of transport, and none of them fetched the kinds of prices that would allow the villagers to improve their standard of living. In addition to growing foodstuffs, the women and children in the villages raised pigs and poultry. While demand for local poultry in particular remained comparatively high, village-level production was inefficient. Due to limited resources in the villages themselves, bulky animal feed had to be imported from outside and then hauled back to the villages.

From the 1950s onward, young people increasingly believed there was little chance of a good future in the rural villages, so they started to migrate to urban areas, or even overseas, for improved job opportunities and better lives. By the 1970s many rural villages had, thus, become depopulated (Hayes 1995). From an economic perspective, rural poverty was a critical problem for many villagers at that time. In order to support their families and secure a better standard of living, many healthy young men left to seek more highly paid work in the towns, where an explosion of cheap labour had led to a large increase in Hong Kong's manufacturing base. Some former villagers even chose 'to work in Chinese takeaways in Britain or serve as merchant mariners' (Sinclair et al. 2007, p. 19), with 50,000 Hongkongers serving in the merchant marine at different times throughout the 1960s. In addition, the transformation of Hong Kong's economy to manufacturing industries saw job opportunities arise for girls from the villages, first in the textile or wig factories in Tseung Wan in the 1960s and then in the electronics and watch factories of Kwun Tong in the 1970s (Sinclair et al. 2007). As a result, only the elderly, wives and young children were left in the villages. Gradually, as the young men grew wealthier, they would move their family members out of the rural villages to join them, paving the way for the desertion of the whole clan from the village.

A further important catalyst for the collapse of rice farming was the post-war education policy of the colony (Sinclair et al. 2007). The British government promoted the establishment of rural schools in the New Territories, aiming at providing primary education for all children living in the villages. Children in the villages attended new rural schools run and promoted by the government, which helped improve the educational level of the villagers. However, a direct consequence of this was that these students could not help their families by working on the farms or taking care of animals, leading to a decline in agricultural output.

\section{Sheung Yiu Village}

The last lime kiln in Sheung Yiu Village was built shortly after the end of the Second World War (Sinclair et al. 2007). However, lime making ceased to be profitable in the 1950s following the introduction and popularisation of building material substitutes, such as imported cement, bricks and mortar. At the same time, lime began to be imported from China and Japan. Chinese lime was cheaper because of the significantly lower labour costs, while Japanese lime was produced by far more efficient industrial processes and the native product of Sai Kung could compete with neither.

In the 1960s, the colonial government started a programme aimed at attracting some of the wealthier villagers in the New Territories to move to Britain to engage in agricultural or industrial work. Due to the challenges facing their activities on the Sai Kung Peninsula, many of the villagers in Sheung Yiu Village decided to leave (Sinclair et al. 2007) and by 1965 the whole village had been abandoned. The father of one informant who resided in Sheung Yiu Village moved to Bristol in the southwest of England and worked in cafes there, before going on to open the first Chinese restaurant in the city. Life was hard for those still living in the Pak Tam Chung region. The lack of an electricity supply until as late as 1977 and the fact that running water only became available in 1979 made the possibility of migrating to Britain look extremely attractive to many villagers.

The majority of the population in the six villages in Pak Tam Chung moved away in the 1960s, with a variety of push and pull factors accounting for this movement. The most important push factor was the road extension works carried out on Sai Kung Road. With the improvement of the road network, other villages in Sai Kung located near the road were better situated to provide pigs to the town at a cheaper price than the six villages in Pak Tam Chung, who all still relied on ferry transportation, undercutting an important element of their agricultural activity. For the pull factors, on the one hand, the Sai Kung road extension to Pak Tam Chung literally paved the way for villagers to work in the town, while, on the other hand, the campaign by the British government attracted many wealthy villagers to move to Britain to start new lives. By the 1970s, the six villages in Pak Tam Chung were almost entirely abandoned.

\section{Country Park from 1978}

At the end of the Second World War, many hills on the Sai Kung Peninsula were left bare, as the Japanese had cut down a large number of trees during the occupation. Once the British resumed control, reforestation was actively promoted by the Botanical and Forestry Department (now under the management of the Agriculture, Fishery and Conservation Department, AFCD), through planting various local and exotic tree species. On the Sai Kung Peninsula, villagers fully supported the government's project to reforest the hill slopes. Adjoining the highly diversified fengshui groves, the newly planted trees grew well in the area

By the 1970s, the aims of the government had become more far-reaching and were also concerned with improving the water supply, as well as the provision of recreational and educational facilities. This led to the creation of a country park system, which now accounts for some 40 percent of Hong Kong's territory. In Sai Kung, the government created the Sai Kung East Country Park (SKECP) on February 3, 1978, taking in a total of 4,477 hectares. The setting up of the Country Park had a profound impact on the lives of the remaining villagers, as many restrictions were now imposed which curtailed their ability to develop their villages and, thus, their livelihoods. According to $\mathrm{Ng}$ (2003), villagers could not renovate their houses without the permission of the AFCD because of the potential waste and water pollution. Activities 


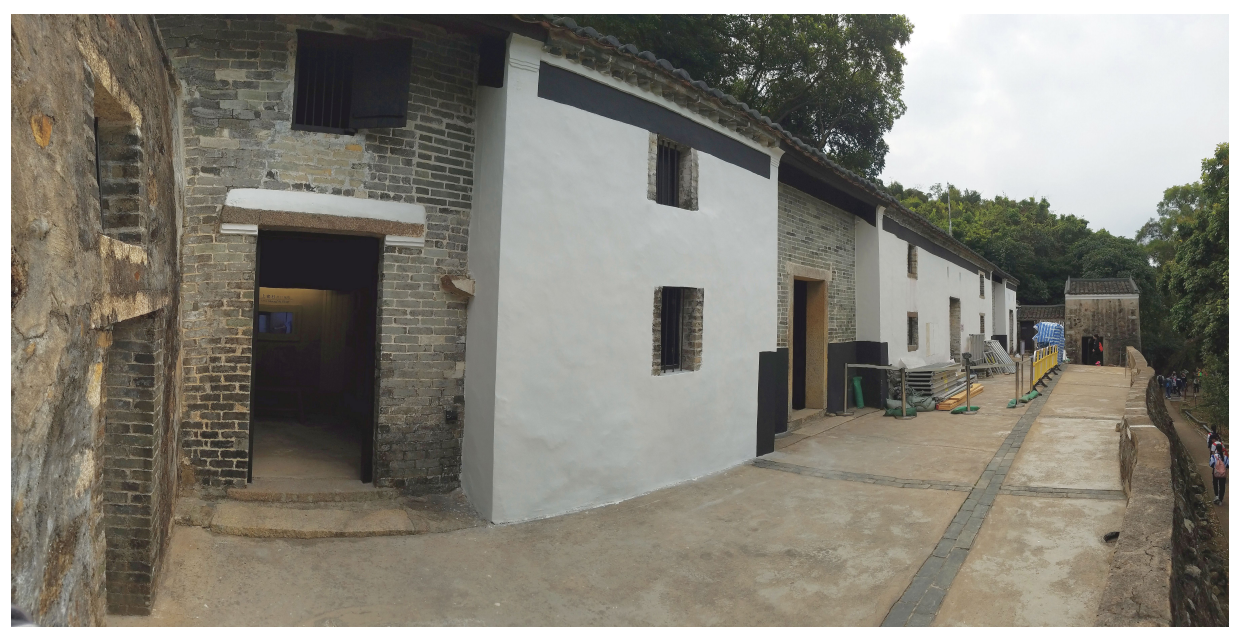

Figure 6. Sheung Yiu hamlet

photo: C. Delang

such as 'planting, weeding and harvesting the twice-yearly rice crop [were] abandoned' (Sinclair 2007, p. 17) and many villages in Sai Kung were 'deserted', some 'losing their entire populations overnight' (Sinclair 2007, p. 17).

From 1972, the government allowed villagers to build a house on village land. Village houses were standardised, and built over three stories on a 700-square-foot plot, to retain the traditional relationship among three generations (Sinclair 2007). However, as more and more traditional village houses were rebuilt in the form of three-storey villas in the Spanish style, the desirable living environment attracted not only the local villagers but also outsiders who wished to rent or purchase villas from the locals. The desertion of these villages began to reverse but, at the same time, the composition of the populations shifted to include a mixture of backgrounds and nationalities.

From the 1980s onwards, awareness of the conservation efforts in the country parks rose among citizens, with ecotourism becoming increasingly popular among the local residents. To cater for the needs of visitors, the government developed several educational and recreational facilities. On November 13, 1981, village houses and the lime kiln of Sheung Yiu Village were declared historical monuments. Restoration works began and the museum was eventually opened to the public in 1984, aiming to preserve a well-established Hakka house in Hong Kong. Inside, the museum hosts a number of different exhibitions showing the lifestyles and livelihoods of Hakka people in the past, with the original furniture in the various rooms, along with information on their original purposes. In addition to the museum, the government developed several hiking trails within the boundary of the SKECP. At the same time, camp sites - under the authority of the AFCD - were developed at various locations, such as Luk Wu, Yuen Wu Fan, Long Ke, Pak Lap and Cheung Sheung. The Sai Kung Peninsula has now completely transformed from a lime-making and farming area into a conservation and recreation zone.

\section{Discussion and Conclusions}

For much of the last 150 years, Hong Kong has acted as a key location for global trade and was, for most of that time, embedded in the international socio-political structure of the British Empire and then, later, its successor, the British Commonwealth. As such, a variety of distant forces and trends - economic, political and technological - have exerted a powerful influence on the way land has been used in the rural hinterland of the city. During the period of British rule, Hong Kong underwent dramatic growth, growing from a small fishing village to become a major global city with a population in excess of 7 million. This rapid development means that the territory can provide a valuable case study for examining the effects of urbanisation and its influence on livelihoods in the nearby rural areas. The relatively small size of this hinterland serves to intensify these effects. The changes experienced in the Sai Kung Peninsula, and in Sheung Yiu village in particular, show the interaction between local forces and those acting from further afield. While the options available to the locals have been limited to some extent by the restrictions imposed upon them by various governmental authorities, the villagers of the peninsula have also had considerable leeway to take advantage of new opportunities as they have arisen.

No governmental intervention is more drastic than that which comes with warfare and the forced relocation of populations. As discussed at the beginning of this paper, in the $17^{\text {th }}$ century the inhabitants of Sai Kung were forcefully relocated from the peninsula. It is likely that few of those who resettled the area afterwards were members of the population who had initially been displaced. The Japanese occupation during WWII also had profound impacts. Even though the effects were not as severe as those that followed the earlier forced relocation of the population, the activities of the villagers were still heavily controlled and their choices severely curtailed by decisions based on military priorities set by distant actors.

The physical environment has had a profound impact on the people living in the Sai Kung Peninsula. To begin with, they settled in the rugged terrain of the Sai Kung Peninsula because the better land - flat areas in the north of the New Territories that could more easily be farmed for rice - was already taken by earlier migrants. With limited choices available, the Wong family, who settled in Sheung Yiu village, turned to one of the few economic activities that could be undertaken in Sai Kung to supplement rice farming and the collection of forest products, namely lime making. This business prospered to such an extent that the Wongs were able to invite relatives - or clan members - to join them in their activities. Yet, lime making requires the extraction of coral and shells, meaning that this activity can only be pursued sustainably on a small scale. By the 1950s, the necessary raw materials were beginning to run out and the industry suffered further from the competition of industrially manufactured lime from Japan and cheaper natural lime from China.

As the local economic opportunities dwindled, people resorted to working in the nascent manufacturing industries, 
gradually abandoning the rural villages to settle closer to the industrial areas in Hong Kong, to serve as merchant mariners, or to work overseas. Legal restrictions on land use and livelihoods were felt again in the late 1970s, when the government set up a country park in the peninsula. This development set considerable limits on livelihoods and economic opportunities for the people of the area, who were no longer able to use the local natural resources as they once had.

The history of the changing livelihoods of the people living in the Sai Kung Peninsula shows that while individuals are able to take advantage of changing opportunities - taking up lime production, or migrating, for instance - the government has the ability to strictly control the boundaries within which people can act, especially when the government is not democratic or otherwise does not consult the locals (as in the $16^{\text {th }}$ century, during the Japanese occupation, or when the Hong Kong government decided to create protected areas). At the same time, particular economic activities are not necessarily sustainable, and nor do they need to be for people to act rationally. In many cases it makes sense for an individual economic actor to use resources in an unsustainable manner. For example, when resource levels increase at very low rates (as is the case for corals) it may often make sense to extract resources at a rate that outstrips replacement, and engage in other activities when they run out. While it is often the case that societies, taken as collective wholes, benefit from the sustainable use of resources, the people who directly depend on them do not necessarily do so. There is, then, a tension between the rational activity of the individual and the rational activity of a government that is responsible for the collective good. So, while it is possible to criticise the government for denying the local people access to natural resources through the creation of the country parks, Hong Kong as a whole likely benefited from these conservationist measures, and those who were displaced by these decisions were eventually able to improve their livelihoods elsewhere.

Recent work on changes in livelihood and economic activities has emphasised the need to move away from simplistic analyses that understand these changes as being caused principally by local economic opportunities. Instead, more sophisticated models are required which acknowledge that livelihood change is driven by a complex web of interacting factors that connect the local and global levels (Liu \& Liu 2016; Prado et al. 2015; Lambin et al. 2001). The village of Sheung Yiu, and the Sai Kung Peninsula more generally, provides a valuable microcosm for understanding the complexities of the interacting forces that drive land use change.
The history of the settlements in the peninsula shows that a variety of measures affect livelihoods in any particular place and that simplistic explanations as to causation and agency are often invalid. One of the conclusions of this paper is that as socioeconomic effects become increasingly globalised and able to act at a distance, they begin to 'overwhelm' localised socio-ecological effects. When they are able to exert their influence, global forces become very important determinants of local changes in livelihood and economic activity. Local factors do not disappear entirely but they are amplified or attenuated by global factors, which become the main driving forces, overwhelming the impetus of the local drivers (Goers et al. 2012; eds. Lambin \& Geist 2008). At the same time, it is clear that environmental degradation may have profound impacts, completely destroying the resource base upon which the economy lies (Azam 2016). Such was the case with the destruction of the local coral.

The literature tends to focus on one change in particular to explain changes in one particular area (Geist et al. 2006). However, if longer time-frames are taken into consideration, we can see that many different factors affect change in the same region at different times. Both fast- and slow-acting (Aide \& Grau 2004; Rudel et al. 2005) socio-economic and socio-ecological factors (Lambin \& Meyfroidt 2010) have been important in driving changes in economic activities in the Sai Kung Peninsula. The early history of the peninsula sees changes in economic activities being driven by a combination of local and distant drivers, with new areas of land exploited by migrants but the contours of their land use being shaped by the geography and ecology of the local area. During the period of British rule changes were increasingly driven by distant factors, such as political and technological developments in foreign countries, and these effects can be seen to have been far stronger in Hong Kong and the New Territories than in the neighbouring coastal regions in China. Since the end of British rule, the forces of a new form of globalisation, independent from the structures of one particular colonial empire, have served to continue the importation of distant drivers, perhaps more strongly than ever. Now, Hong Kong is no longer an isolated colonial outpost that is unusually sensitive to the ebbs and flows of distant trends. The global drivers that act on Hong Kong now act on the rest of China as well and the impacts of distant forces show themselves also in the neighbouring regions that once served to cast Hong Kong into unique relief. Hong Kong will continue to be a fascinating and vibrant city for many years to come but now much of the rest of the world has come to share in its networked and connected status.

\section{References}

Aide, TM \& Grau, HR 2004, 'Globalization, migration, and Latin American ecosystems', Science vol. 305, pp. 1915-1916.

AMO 2005, History and Development of Sai Kung. The Government of the Hong Kong Special Administrative Region, Antiquities and Monuments Office, Hong Kong.

Azam, M 2016, 'Does environmental degradation shackle economic growth? A panel data investigation on 11 Asian countries', Renewable and Sustainable Energy Reviews, vol. 65, pp. 175-182.

Centre for East Asian Studies 1980, Saikung, 1940-1950: The Oral History Project, Centre for East Asian Studies, Chinese University of Hong Kong, Hong Kong.

Cheng, P 2003, A century of New Territories roads and streets, Joint Publishing (H.K.) Co. Ltd, Hong Kong.

Faure, D 1986, The structure of Chinese rural society: Lineage and village in the eastern New Territories, Hong Kong, Oxford University Press, Hong Kong.
Geist, H, McConnell, W, Lambin, EF, Moran, E, Alves, D \& Rudel, T 2006. 'Causes and trajectories of land-use/cover change' in Land-use and land-cover change, eds EF Lambin \& HJ Geist, Heidelberg, Springer, pp. 41-70.

Goers, L, Lawson, J, \& Garen, E 2012, 'Economic drivers of tropical deforestation for agriculture' in Managing Forest Carbon in a Changing Climate, eds. MS Ashton, ML Tyrrell, D Spalding \& B Gentry, pp. 305-320, Springer, Netherlands.

Hong Kong Government 1913, 'Report on the New Territories, 1899-1912', Government Printer, Hong Kong.

Lambin, EF \& Geist, HJ (eds.) 2008, Land-use and land-cover change: local processes and global impacts, Heidelberg, Springer.

Lambin, EF \& Meyfroidt, P 2010, 'Land use transitions: Socioecological feedback versus socio-economic change', Land use policy, vol. 27(2), pp. 108-118. 
Lambin, EF, Turner, BL, Geist, HJ, Agbola, SB, Angelsen, A, Bruce, JW, Coomes, OT, Dirzo, R, Fischer, G, \& George, $P$ 2001, 'The causes of land-use and land-cover change: moving beyond the myths', Global environmental change, vol. 11(4), pp. 261-269.

Liu, R 1999, Simple History of the New Territories (新界簡史), Joint Publishing Company Limited, Hong Kong.

Liu, Z \& Liu, L 2016, 'Characteristics and driving factors of rural livelihood transition in the east coastal region of China: $A$ case study of suburban Shanghai', Journal of Rural Studies, vol. 43, pp. 145-158.

Lockhart, JHS 1898, Report on the Extension of the Colony of Hong Kong, Colonial Office, London

Ma, M, Cheung, SW, Wong, WH, Liu, TS, Lau, YC \& Tsoi, CC 2003, Sai Kung history and cultural heritage (西貢歷史與風 物), Sai Kung District Council, Hong Kong.

Prado, DS, Seixas, CS, \& Berkes, F 2015, 'Looking back and looking forward: Exploring livelihood change and resilience building in a Brazilian coastal community', Ocean \& Coastal Management, vol. 113, pp. 29-37.
Rao, J 1998, The exploration of the names of Hong Kong places (香港地名探索), Cosmos Books Ltd, Hong Kong.

Rao, J 2001, The old relics of Hong Kong (香港舊風物), Hong Kong: Cosmos Books Ltd.

Rudel, TK, Coomes, OT, Moran, E, Achard, F, Angelsen, A, Xu, J \& Lambin, E 2005, 'Forest transitions: Towards a global understanding of land-use change', Global Environmental Change, vol. 15, pp. 23-31.

Schenk, C 2008, 'Economic History of Hong Kong' in EH.Net Encyclopedia, ed. R Whaples. Available from: <http:// eh.net/encyclopedia/economic-history-of-hong-kong/>. [16 March 2008].

Sinclair, K, O'young, A \& Lui, P 2007, Living villages: how modern Hong Kong's rural legacy is being kept alive, SCMP Book Publications, Hong Kong.

Stokes, E 2004, Venturing Sai Kung East (新西貢山海美), Friends of the Country Parks, Cosmos Books, Hong Kong. 